\title{
Farming in crisis and the voice of silence - a response to David Atkinson
}

\author{
S. P. Carruthers* \\ John Ray Initiative, Francis Close Hall, University of Gloucestershire, Swindon Road, Cheltenham GL 50 4AZ, United Kingdom
}

\begin{abstract}
In considering the role of religious assumptions in making environmental decisions in agriculture, the idea of sabbath is proposed as offering a radical critique of the present agricultural situation and a robust, holistic basis for agricultural ethics. The sabbath, with its emphasis on restraint, including in the use of the land, complements stewardship, which emphasises care and responsibility. In the current farming crisis, the sabbath urges us to recognise and respect both people and the earth, to subordinate the pursuit of private wealth to meeting the needs of the poor and vulnerable, and to restrain the concentration of power and control.
\end{abstract}

Resale or republication not permitted without written consent of the publisher

The aim of this Consultation is to examine the role of religious assumptions in making environmental decisions. This paper considers the ethical basis for environmental decision making provided by some biblical themes related to agriculture and the land, examines the present context of decision making, specifically the global crisis in farming, and considers how biblical theology may offer an holistic approach. The sabbath is proposed as offering a radical critique of the present agricultural situation and a robust holistic foundation on which to construct ethics for agriculture.

\section{ETHICS FOR ENVIRONMENTAL DECISION MAKING}

\section{Ruling and caring}

Atkinson depicts the 2 biblical creation accounts as offering contrasting, and by implication contradictory, 'models' for human treatment of the environment. The first mandates 'rule' or 'dominion' (Genesis 1:28); the second advocates 'tending' and 'caring' (Genesis 2:15).

However, examination of the biblical texts and con-

*E-mail: pcarruthers@glos.ac.uk text shows that these are not contradictory, but complementary - different emphases of the same calling, opposite sides of the same coin. Both enjoin responsibility for the earth and support a theology of stewardship. Both reflect the image of God Himself.

The issue rests particularly on the interpretation of the 'dominion' or 'rule' (radah) of Genesis 1:28, as meaning, or mandating, 'domination' or 'mastery'. According to Bauckham (2002), from the viewpoint of biblical exegesis, this interpretation has been refuted many times. The word refers to the rule of Israelite kings, but Israelite kings were not to be like other kings (Deuteronomy 17:14-20). Their rule was not to be absolute or despotic, but rather as that of viceroys of God on earth, and servants of their people (1 Kings $12: 7)$; their delegated power was to be held on trust from him; their duty was to exercise mercy and justice towards His creatures (Bauckham 2002, Bradley 1990). Especially, the king had a responsibility to 'manage the land as gift entrusted to him, but never possessed by him' (Breuggemann 1977, p 75).

The key words in Genesis 2:15 are 'tend' (abad) and 'care for' (shamar). Abad is elsewhere translated serve and has the meaning of work on behalf of another, including military service or cultivating the land for a master, or for the king. The related noun is commonly translated servant. Shamar has the meaning of protecting or guarding, and appears at the end of the Eden 
account when a flaming sword is placed to guard (shamar) the tree of life (Genesis 3:24).

Ultimately, these mandates reflect the nature of God Himself, who not only is the eternal Creator and Lord of creation, but also sustains His creation and is intimately acquainted with His creatures (Psalm 50:11; Luke 12:6-7), providing for their needs (Psalm 104; Luke 12:24). Hence, if both dominion and care are reconciled in God, then there was to be no conflict in people made in His image. Mankind was intended to rule over and care for creation with compassion and mercy, like to that of God Himself.

\section{The wisdom of the Greeks}

However, as Atkinson states, 'the dominance model has, in the past, had a significant resonance'. He quotes examples of those, such as John Calvin and John Henry Newman, whose words bear out the view that the non-human creation has been understood as existing purely for human benefit. He could, of course, have cited many others from the history of Christendom and Western philosophy. ${ }^{1}$

However, this interpretation of 'dominion' as 'dominance' or 'domination', though it has prevailed through much of Christian and Western history, arises not from the intention of the biblical text, but from the profound influence on Western civilisation and Christian theology of Greek philosophy, especially, as Bauckham (2002) argued, as developed through Italian Renaissance humanism and Francis Bacon's vision of scientific progress.

The contradiction, then, is ultimately not between Genesis 1 and Genesis 2, but between Hebraic and Hellenistic worldviews, between the theocentric view of the Hebrew scriptures and the anthropocentric view of Greek philosophy and its developments - the view that 'man is the measure of all things'.

\footnotetext{
${ }^{1}$ Aquinas (1225-1274) believed that only humans possess intellects on earth and that the remainder of God's earthly creation is under human dominion (Armstrong \& Botzler 1993, p 278). Descartes (1596-1650) concluded that animals had neither minds nor consciousness and were no more than machines with parts assembled in intricate ways. Humans, therefore, have little responsibility to other animals or the natural world, unless the treatment of them affects other humans (Armstrong \& Botzler 1993, p 281). Kant (1724-1804) asserted that only rational beings merit moral concern and only humans are rational (Armstrong \& Botzler 1993, p 285). Both Aquinas and Kant tempered their views, however, arguing that those who ill-treated animals would ill-treat people also. 'Tender feelings towards dumb animals develop humane feelings towards mankind'; 'a master who turns out his ass or dog because the animal can no longer earn its keep manifests a small mind' (Kant, quoted in Armstrong \& Botzler 1993, p 286)
}

\section{Keeping the Sabbath}

It is clear that the dominion mandate has had a rough ride through history. Its misinterpretation has both legitimised 'playing fast and loose' with the environment and provoked trenchant criticisms of Christianity's environmental record, such as those of historian Lynn White (1967). Nevertheless, correctly interpreted and alongside its counterpart in Genesis 2:15, it has provided the basis for the idea of stewardship of creation, an environmental ethic that has gained wide acceptance, both among Christians and more widely (Bauckham 2002, Berry 1999, John Ray Initiative 2000).

Stewardship emphasises care and responsibility and seeks to counter utilitarian attitudes to, and aggressive domination, of non-human creation. Stewardship, however, may only tell part of the story, particularly in relation to the present situation in agriculture, which calls not only for care, but also for restraint, and for approaches that reconcile the needs of people and the earth.

A complement to stewardship is found in the biblical sabbath. By emphasising restraint, the sabbath challenges the fundamental modus operandi of modern agriculture, in its environmental, economic and social dimensions, and offers a radical ethic to guide environmental decision-making and to tackle the wider considerations confronting farming and the global food system.

The Bible does not proscribe economic growth, but it does prescribe measures to limit its growth at the costs of injustice, oppression (Wright 1983), ill-treatment of domestic livestock and over-exploitation of the land. Economic growth, through exchange and trade and through agricultural production from the land, is intended to be subordinate to the principles of love of neighbour ${ }^{2}$ and care for the earth.

This principle of restraint, on the use of land, livestock and labour, on the concentration of wealth, and on expansionism, can be discerned in many biblical themes and writings ${ }^{3}$, but it is most forcefully conveyed through the sabbath.

The sabbath day was instituted as a day of rest not only for people, but also for livestock (Exodus 20:8-11).

\footnotetext{
${ }^{2}$ The Old Testament (agricultural) economy shows a special concern for the vulnerable and the poor. Laws of tithing (Deuteronomy 14:28-29) and gleaning (Deuteronomy 24:19-22), for example, make provision for those without assets, protection or power (i.e. strangers, widows, orphans) those who have no standing ground in the community (Breuggemann 1977). The prophetic vision of Isaiah 61:1, the passage chosen by Jesus Himself to announce His ministry (Luke 4:18-19), sees the year of the Lord's favour as being marked by the 'binding up of the broken hearted' and the 'freeing of the oppressed'
} 
Essentially, the (legitimate) work (i.e. of tending the land) of 6 days of the week was to cease on the 7 th, reflecting the pattern of God's own work of creation. The sabbath day anticipated the sabbath year, a year for freeing slaves (Exodus 21:1-11), cancelling debts (Deuteronomy 15:1-11) and resting the land itself (Leviticus 25:1-7).

The sabbath year anticipated the Jubilee (Leviticus 25:8-55), a sabbath of sabbaths, in which in addition to all the provisions of the sabbath year, 'each was to return to his property and each to his family'. The Jubilee emphasised the inalienability of family land (see 1 Kings 21:3), and, in effect, placed strict limits on the growth of private wealth. As land could not be sold permanently, amassing huge private estates was technically impossible (Wright 1983).

Sabbath day, sabbath year and Jubilee, also point beyond themselves to the Messianic age, to the releasing of the oppressed, to God's justice and righteousness in everything, to freedom for the land, to the liberation of creation. 'It was with the announcement of this "messianic sabbath" (Moltmann 1985, p 291) that Jesus began his public ministry (Luke 4:18).' The sabbath both looks back to the rest of creation and looks forward to its redemption (Moltmann 1985).

\section{Constraining covetousness}

The sabbath places a radical constraint on relentless production (and, by implication, consumption) and unbridled covetousness. The sabbath protects those without a voice and without power - the poor, livestock and the land. The sabbath reminds us that the land is a gift and the earth and everything in it are not ours to do

\begin{abstract}
${ }^{3}$ For example, the taking of interest in loans was prohibited between Israelites (Exodus 22:25, Leviticus 25:36, Deuteronomy, 23:19); there was strict control on what could be taken as pledges in security for loans and how (e.g. Exodus 22:26; Deuteronomy $24: 6,10$ ), the moving of boundary stones that marked out family land was strictly proscribed (Deuteronomy 19:14) (see Wright 1983, p 83-84). Standards for the care of domestic animals are emphasised by commandments not to 'plough with an ox and an ass together' (Deuteronomy 22:10) or 'muzzle an ox when it treads out the grain' (Deuteronomy 25:10), as well as the inclusion of livestock in the keeping and blessing of the Sabbath (Exodus 20:8-11). 'Regard for the life of his beast' is a mark of a righteous man (Proverbs 12:10)
\end{abstract}

\footnotetext{
4 'Sabbath sets a boundary to our best, most intense efforts to manage life and organise land for our security and wellbeing. Land sabbath is a reminder that (a) land is not from us, but is a gift to us, and (b) land is not fully given over to our satiation. Land has its own rights over against us and even its own existence. It is in covenant with us, but not totally at our disposal. Sabbath is for honouring land' (Breugemman 1977, p 63-64)
}

with what we will, but the Lord's ${ }^{4}$. The sabbath affirms that 'I am, indeed, my brother's keeper'.

Yet the temptation for landed people, those with assets, position and power, those who control the means of production, is to create a sabbathless society 'in which land is never rested, debts are never cancelled, slaves are never released, nothing is changed from the way it now is and has always been' (Breugemman 1977, p 65).

\section{Restraining productionism}

How, then, does the sabbath relate to the present agricultural situation? As Thompson (1995) put it, modern industrial agriculture is predicated on the 'productionist paradigm', the principle that more production is always better. Since World War II, productionism has come to dominate the agriculture of developed countries, a phenomenon he attributes to the opportunities provided by technology - mechanisation, inorganic fertilisers, pesticides, veterinary medicine, and plant and animal breeding. This 'technocentric productionism, the headlong and unreflective application of industrial technology for increasing production, is antienvironmental' (Thompson 1995, p 70). As Atkinson shows, technology is the source of many of modern agriculture's negative environmental impacts (eg inorganic fertilisers, pesticides and herbicides) or raises serious environmental questions (e.g. GM crops).

This is not to say that it is only technological agriculture that damages the environment. There are plenty of examples of pre-industrial agriculture's destructive effects on the environment, from both ancient and recent history. Nor is it to say that technical innovation has not also been the means by which food supplies have been maintained.

Nevertheless, modern agriculture has produced unprecedented excesses. For example, the combination of technology and productionism has transformed traditional patchwork landscapes into vast areas of monoculture, and enabled animals to be exploited as machines in factory farms on scales never before dreamed of. As Pretty (1998) argued, the legacy of modern agriculture is a 'dying land' and 'dying rural communities'.

Productionism, without restraint, without reference to another ethic, is tantamount to 'coveting without limit'. To which, as described above, the sabbath provides a radical and comprehensive critique and corrective. For agriculture, then, the choice is between restraint, in recognition and care of neighbour, livestock and land, and unbridled production and consumption, between keeping the sabbath and a sabbathless society. 


\section{CRISIS AS CONTEXT}

\section{The farming crisis}

Decision making cannot be abstracted, detached from the context within which those decisions are made or implemented. Such decisions will, and must, be earthed, rooted, and grounded in the realities of farming. And that reality is, at present, a crisis. Two aspects of that crisis are particularly significant: the downturn in the fortunes especially of family and peasant farming worldwide, and the growth of corporate power in the global farming and food system.

In the UK, as elsewhere, farm incomes have declined markedly in the last few years, as have the numbers of full-time farmers and farm-workers, numbers of farms, and agriculture's contribution to national economy. ${ }^{5}$ On the increase are part-time farming and farm employment, average farm size, public interest and consumer pressures, regulation and bureaucracy, and stress and despondency among farmers. The crisis has been deepened in the last few years by BSE, classical swine fever, the exceptionally wet autumn of 2000/01 and foot-and-mouth disease in 2001. For some, the crisis in farming is a crisis of existence, and a poignant indicator and symbol of this has been the increased incidence of suicide among farming people.

Agriculture has also had an immense impact on the environment, in a wide range of respects, and, while there are signs of a slowing of some negative impacts (Countryside Agency 2001), agriculture's burden on the environment remains considerable. ${ }^{6}$

For farmers, concern for the environment is both an opportunity and a threat. Farming's role in shaping and conserving the countryside is increasingly recognised. And, as a rationale for continued public expenditure on agriculture, for example as recommended by

\footnotetext{
${ }^{5}$ At $£ 1.88$ billion, total income from farming (TIFF) in the UK in 2000 was at its lowest for 25 yr (DEFRA 2002; Countryside Agency 2001). Estimated average farming income per head was $£ 7800$ (Countryside Agency 2001). In the same year, agriculture's contribution to the national economy (GVA) was just $0.8 \%(88 / 91=1.5 \%)$ (although the food sector as a whole contributed $8 \%$ ) (DEFRA 2002). Public expenditure for 2001 is forecast at $£ 4.75$ billion
}

\footnotetext{
${ }^{6}$ Pretty et al. (2000) estimated the external costs of UK agriculture in 1996 in terms of environmental and health impacts at $£ 2.34$ billion (equivalent to $£ 208$ per ha from all of arable and permanent pasture and £229 per ha arable; pesticides alone cost $£ 33$ per ha of land receiving pesticides). Significant costs arose from emissions of gases (£1113 m), contamination of drinking water with pesticides $(£ 120 \mathrm{~m})$, nitrate ( $£ 16 \mathrm{~m})$, Cryptosporidium $(£ 23 \mathrm{~m})$ and phosphate and soil (£55 m), damage to wildlife, habitats, hedgerows and dry stone walls ( $£ 125 \mathrm{~m})$, soil erosion and carbon losses ( $£ 106 \mathrm{~m}$ ), food poisoning ( $(169 \mathrm{~m})$ and BSE ( $£ 607 \mathrm{~m}$ ) (Pretty et al. 2000)
}

the recent Policy Commission on the Future of Farming and Food (2002), or the force behind new markets for organic food and local produce, the environment may appear to be the 'saviour' of farming.

But the environment is also a threat. Farming's negative impacts on the environment, as well as the related issues of animal welfare and food safety, have occasioned much public scrutiny and antipathy. Environmental regulation has added to the bureaucratic burden of farmers. Some farmers would argue that environmental and animal welfare legislation has weakened the UK's ability to compete with less regulated overseas producers. Further regulation threatens farmers unable to comply or deliver the new environmental goods.

\section{Global power}

Control of the world's food system has become increasingly concentrated in the hands of commodity traders, seed and agrochemical companies and retailing groups. ${ }^{7}$ 'The relationship between consumers and producers is now mediated by powerful commercial players', and producers are increasingly powerless, especially family farms and peasant farmers. 'Whilst returns to producers have shrunk, profit margins of food manufacturers, transporters and supermarkets remain steady or are increasing' (Farmers Link 2001 et al.).

The combination of corporate power and technocentric productionism is vividly seen in the world banana trade. According to Madeley (1999), the trade is dominated by just 3 transnational corporations (TNCs), which together control around $70 \%$ of world exports. 'Large tracts of land have been taken over by the banana companies ... driving people from their land and work. The environment has suffered as banana TNCs have grown bananas in monoculture fashion and used huge amounts of toxic pesticides on their plantations. Small producers ... find it difficult to compete with the giants' (Madeley 1999, p 5).

\section{Deciding in crisis}

In the context of crisis, then, how do we make environmental decisions for agriculture? As Atkinson describes, agriculture presents a complex array of questions calling for decisions about the balance between one or other outcome or trade-offs between

\footnotetext{
${ }^{7}$ For example, according to Madeley (1999), one transnational corporation (TNC) controls half of the world's grain trade
} 
different impacts. Where actions, including the use of technology, harm both people and planet, as in the case of bananas, the ethical imperative is clear. Less straightforward, however, are situations where serving environmental goals may be to the disadvantage of producers.

The context of crisis does not make decision making any easier, but it may help to identify some leading issues, as above. The sabbath and Jubilee provide a radical and comprehensive critique and corrective, urging us to recognise and respect both people and the earth, to subordinate the pursuit of private wealth to meeting the needs of the poor and vulnerable, and to restrain the concentration of power and control.

\section{BIBLICAL HOLISM}

'Agriculture' and 'environment' are usually considered as things apart, and agriculture's environmental impact (and by implication making environmental decisions regarding the use of technology) is analysed in terms of a number of measurable environmental impacts. ${ }^{8}$ However, agriculture is both an ecosystem in itself and part of the larger human biotic community (Thompson 1995), connected in a multiplicity of ways. The quest for sustainable agriculture reflects the framing of agriculture in relation to both the natural environment and human society, in both its present and its future.

How might perspectives from the Bible help in achieving a holistic understanding of agriculture? One key is found in the uniqueness of 'land'. ${ }^{9}$ Land is not like anything else. Its uniqueness means that it cannot be reduced simply to a factor of production, a com-

\footnotetext{
${ }^{8}$ This is reflected, for example, in the indicators developed, for example, by MAFF (2000) and OECD (2001). These document the effects of farming on key environmental categories. They are increasingly less easy to measure and less meaningful at higher levels of integration (e.g. landscapes)
}

\footnotetext{
${ }^{9}$ As Breuggemann (1977, pp 2-3) stated, 'land is always freighted with social meanings derived from historical experience .. always fully historical, but always bearer of overpluses of meaning known only to those who lose and yearn for it'

${ }^{10}$ Hear the word of the Lord, you children of Israel, for the Lord brings a charge against the inhabitants of the land. There is no truth or mercy or knowledge of God in the land. By swearing and lying, killing and stealing and committing adultery, they break all restraint, with bloodshed after bloodshed. Therefore the land will mourn; and everyone who dwells there will waste away, with the beasts of the field and the birds of the air; even the fish of the sea will be taken away (Hosea 4:1-3)
}

modity to be bought and sold. It follows, then, that agriculture cannot be regarded as just any other business or farming reduced to simply 'land management'. Farming's intimate association with the land makes it a unique privilege and a unique responsibility. The dislocation of farming and the land, and its reduction to mere economic categories, are surely central to the environmental and social crisis in farming.

However, 'biblical holism' goes further than that. In a recapitulation of Genesis 3 and 4, the prophet Hosea explained ancient Israel's agricultural and environmental crisis, in terms of moral and social breakdown and national apostasy. ${ }^{10}$ Environmental problems, therefore, are not just the result of environmental mismanagement, but are something to do with society as a whole. Environmental solutions, decision-making about the environment, therefore, cannot be just about better environmental management. Such a view is unlikely to be popular or acceptable, or have much resonance, in a society where not only life, but morality is compartmentalised and disconnected. Yet Hosea and the prophets challenge this compartmentalisation. In Hosea, the root of Israel's environmental, agricultural and social crisis was Israel's national apostasy. In Genesis, the root of humanity's disharmony with creation and conflict among people was the broken relationship with God.

Again the Sabbath provides a unifying focus. The sabbath is for all, for both people and the land, for both employers and workers, for both citizens and strangers. It does not allow a pick-and-mix approach, or offer choice in its objects of care. The sabbath is holistic.

\section{POSTCRIPT - 'THE VOICE OF SILENCE'}

This response does not attempt even to address all the questions raised by David Atkinson, let alone the vast array of issues implicit in considering environmental decision making in agriculture. Rather, it offers a foundation upon which to build, some signposts to guide us through the complexities and challenges that face us. But what of the 'voice of silence' of the title?

In his flight from Jezebel following his show-down with the prophets of Baal on Carmel, Elijah travelled south finding his way finally to 'Horeb, the mountain of God'. Summoned from his hiding in a cave he goes out and stands on the mountain '... before the Lord. And behold, the Lord passed by, and a great and strong wind tore into the mountains and broke the rocks in pieces before the Lord, but the Lord was not in the wind; and after the wind an earthquake, but the Lord was not in the earthquake; and after the earthquake a fire; and after the fire a still small voice' - literally 'a voice of thin silence' (1 Kings 19:11-12). 
God's works were evident in the wind, earthquake and fire, but God Himself was somehow present in the silence. The silence following the works echoes the sabbath following the creation. As Moltmann (1985, p 280) stated, 'the works of creation show God exoterically and indirectly, as it were, as Creator. But the sabbath, in its peace and its silence, manifests the eternal God at once esoterically and directly as the God who rests in his glory. That is why the sabbath of creation is already the beginning of the kingdom of glory - the hope and future of all created beings'.

Perhaps, in rediscovering the sabbath for farming, we can find that peace and stillness, for beleaguered people, animals and the land. Perhaps after the fire of the farming crisis, and the literal fires of the UK's recent foot-and-mouth disease epidemic, we can in the sabbath beyond our own works and even the works of God, find the very presence of God Himself.

\section{LITERATURE CITED}

Armstrong SJ, Botzler RG (1993) Environmental ethics. Divergence and convergence. McGraw-Hill, New York

Bauckham R (2002) God and the crisis of freedom: biblical and contemporary perspectives. Westminster John Knox Press, London, Louisville

Berry RJ (1999)A Christian approach to the environment. Transformation 16:73-74

Bradley I (1990) God is green. Darton, Longman and Todd, London

Editorial responsibility: R.J. (Sam) Berry,

London, United Kingdom
Brueggemann W (1977) The land. Fortress Press, Philadelphia

Countryside Agency (2001) The state of the countryside 2001. Countryside Agency, Cheltenham

DEFRA (2002) Summary of UK food and farming. www.defra.gov.uk/esg/m_overview.htm.

Farmers' Link, Agricultural Christian Fellowship, Farmers World Network \& Arthur Rank Centre (2001) Food awakening. Farmers World Network, Stoneleigh

John Ray Initiative (2000) Environmental Stewardship. Occasional Paper. John Ray Initiative, Cheltenham

Madeley J (1999) Introduction: from cradle to grave. In: Madeley J (ed) Hungry for power. UK Food Group, London

MAFF (2000) Towards sustainable agriculture. A pilot set of indicators. Ministry of Agriculture, Fisheries and Food, PA4583, London

Moltmann J (1985) God in Creation. An ecological doctrine of creation. SCM Press, London

OECD (2001) Environmental indicators for agriculture, Vol 3: methods and results. OECD Publication Service, Paris

Policy Commission on the Future of Farming and Food (2002) Farming and food. A sustainable future. Crown Copyright

Pretty JN (1998) The living land. Earthscan, London

Pretty JN, Brett C, Gee D, Hine RE, Mason CF, Morison JIL, Raven H, Rayment M, van der Bijl G (2000) An assessment of the external costs of UK agriculture. Agricult Syst 65(2):113-136

Thompson PB (1995) The spirit of the soil. Agriculture and environmental ethics. Routledge, London

White L (1967) The historic roots of our ecologic crisis. Science 155:1203-1207.

Wright CJH (1983) Living as the people of God. The relevance of Old Testament ethics. Inter-Varsity Press, Leicester

Submitted: September 4, 2002; Accepted: September 7, 2002 Proofs received from author(s): September 23, 2002

Published on the web: September 26, 2002 